\title{
A interconexão do processo de contas com o processo judicial a partir da Operação Lava Jato
}

The interconnection of court of accounts process with the judicial process in context of Car Wash Operation (Brazil)

Francisco Sérgio Maia Alves ${ }^{1}$

\section{RESUMO}

Este trabalho visa analisar a interconexão entre o processo de controle externo e o processo judicial, no contexto da Operação Lava Jato. Para tanto, serão examinados o problema da multiplicidade dos órgãos de controle e, de modo especial, os impactos da atuação do Ministério Público Federal e da instância judicial sobre a atividade do Tribunal de Contas da União. Na sequência serão discutidas a repercussão dos acordos de leniência sobre o exercício das competências do TCU e algumas questões controvertidas dessa relação de interdependência. Para cumprir esses objetivos, será promovida uma análise sistematizada da jurisprudência do TCU e dos tribunais judiciais, no propósito de construir uma visão concreta do tema em análise. Ao final do trabalho, constatou-se que o advento do instituto de leniência criou dificuldades adicionais à busca de uniformidade e coerência do sistema de controle brasileiro, devido à sobreposição de funções entre os diversos órgãos integrantes. Não obstante, percebeu-se uma atuação mais harmônica entre as diversas instâncias, que estabeleceram condições para o uso de provas compartilhadas contra o colaborador. O próximo desafio será a construção de um balcão único de leniência, com vistas à melhoria da alavancagem investigativa e da eficiência processual.

Palavras-Chave: Sobreposição do Controle. Acordo de Leniência. Compartilhamento de Provas. Tribunal de Contas da União.

$1 \quad$ Mestre em Direito e Políticas Públicas pelo Centro Universitário de Brasília (UniCEUB). Graduado em Direito pela Universidade Federal da Paraíba (UFPB) e em Engenharia Civil Aeronáutica pelo Instituto Tecnológico de Aeronáutica (ITA). Atualmente é Auditor Federal de Controle Externo no Tribunal de Contas da União e Assessor de Ministro. E-mail: franciscoma@tcu.gov.br 


\section{ABSTRACT}

The present work aims to analyze the interconnection between the Court of Accounts process and the judicial process, in the context of Operation Lava Jato. Therefore, will be examined. the problem of the multiplicity of control bodies and, in particular, the impact of the actions of the Federal Prosecution Service of Brazil and the judicial body on the activity of the Federal Court of Accounts. In sequence, will be discussed the repercussions of leniency agreements on the exercise of TCU's competencies and some controversial issues of this relationship of interdependence. To achieve these purposes, will be promoted a systematized analysis of the jurisprudence of the TCU and the judicial courts, in order to build a concrete vision of the subject under analysis. At the end of the work, it was found out that the advent of the leniency institute created additional difficulties in the search for uniformity and coherence in the Brazilian control system, due to the overlapping of functions between the various member bodies. However, a more harmonious performance was perceived among the different instances, which established conditions for the use of shared evidence against the beneficiary. The next challenge will be the construction of a one-stop shop for leniency, with the aim of improving investigative leverage and procedural efficiency.

Keywords: Superposition of control. Leniency Agreement. Sharing of Evidence. Federal Court of Accounts.

Recebido: $28-08-2020$

Aprovado: 07-10-2020 


\section{INTRODUÇÃO}

A atuação do Tribunal de Contas da União (TCU), no controle das finanças públicas e dos princípios que lhes são correlatos, sobrepõe-se à do Ministério Público Federal (MPF), em especial, quando este órgão exerce as funções de zelar pela observância desses princípios e de defender os bens e interesses relativos ao patrimônio nacional (arts. 50, inciso II, alínea "b", e inciso III, alínea "a”, da Lei Complementar 75, de 20 de maio de 1993).

O exercício dessas missões pelo MPF é concretizado mediante a interposição de ações civis públicas, para a reparação de danos causados à proteção do patrimônio público (art. $1^{\circ}$, inciso VIII, da Lei $n^{\circ} 7.347$, de 24 de julho de 1985) e de ações de improbidade administrativa, para a aplicação de sanção e eventual ressarcimento em função de atos que importem enriquecimento ilícito, causem prejuízo ao erário ou atentem contra os princípios da Administração Pública (arts. 9º 10 e 11, da Lei n ${ }^{\circ} 8.429$, de 2 de junho de 1992).

Tal situação de sobreposição de funções entre o TCU e o MPF se tornou ainda mais evidente com os desdobramentos da Operação Lava Jato, que descortinou uma série de ilícitos penais, civis, administrativos e financeiros que adentraram na zona de sobreposição do controle realizada pelos aludidos órgãos.

O objetivo desse artigo é analisar a interconexão entre o processo de contas e o processo judicial, em especial, os efeitos dos atos praticados na esfera judicial sobre os da esfera controladora, no que se refere aos ilícitos desvendados na paradigmática Operação Lava Jato.

Para a consecução das finalidades do presente trabalho, serão expostos o espaço de sobreposição entre os diversos órgãos de controle e o incremento das zonas de potencial tensão, especificamente em função do advento do instituto da leniência.

Na sequência, serão verificados os impactos, em concreto, dos pro- 
cessos judiciais da Lava Jato sobre o exercício das competências constitucionais do TCU. Nesse contexto, serão expostos os posicionamentos da $5^{\text {a }}$ Câmara de Coordenação e Revisão (CCR) do MPF e do TCU em determinados casos concretos, a respeito da repercussão dos acordos de leniência sobre as competências do Tribunal.

Adiante, serão apresentadas algumas questões controvertidas que sobressaem da interconexão entre os processos judiciais e os de controle externo. Nesse ponto, serão expostos os precedentes a respeito dos limites eventualmente existentes sobre o uso de provas compartilhadas contra os colaboradores e a possibilidade de decretação de indisponibilidade de bens de colaboradores.

Para cumprir o propósito deste trabalho, será adotado o método de abordagem indutivo, ou seja, serão analisados os processos de controle externo que tratam de fatos conexos aos identificados na Operação Lava Jato, até atingir uma conclusão de ordem geral a respeito do tema em discussão.

Quanto às técnicas de pesquisa, será utilizada basicamente a pesquisa jurisprudencial, tanto em razão do objetivo do trabalho, que é a descoberta da relação concreta entre a atuação de duas instâncias de controle, como em função da escassa produção acadêmica envolvendo esse problema.

A fim de preservar a integridade das sociedades empresárias e pessoas citadas nos trechos de votos e decisões transcritas neste trabalho, substituíram-se os nomes dos envolvidos pelas expressões Colaborador, Colaboradora e Empresa, conforme o caso.

\section{SOBREPOSIÇÃO DO CONTROLE}

Como é cediço, compete ao TCU promover o controle externo da Administração Pública, em auxílio ao Congresso Nacional. Dentre as diversas competências que lhe foram atribuídas, no art. 71, da Constituição Federal, cabe destacar as de julgar as contas dos administradores e daqueles que derem causa à perda, ao extravio ou a outra irregularidade de que 
resulte prejuízo ao erário público; de avaliar a legalidade de atos e contratos; e de aplicar as sanções estabelecidas em sua lei orgânica.

Nesse cenário, a atuação do TCU, no controle das finanças públicas e dos princípios correlatos, sobrepõe-se com a do MPF, em especial no campo do controle da moralidade, da probidade administrativa e da legalidade dos atos praticados em face da Administração Pública e do patrimônio público federais.

Essa situação de interseção entre as duas zonas de controle se torna ainda mais complexa quando os ilícitos investigados se enquadram como crimes contra a Administração Pública Federal e, por consequência, adentram o campo de atuação da justiça criminal. Em face das múltiplas repercussões da infração cometida, surgem variadas possibilidades de ação contra os autores do ilícito, que podem responder, simultaneamente, a processos criminais, civis, de improbidade administrativa e de controle externo.

Em verdade, esse cenário de sobreposição de competências persecutórias possui mais atores, uma vez que os atos de improbidade administrativa podem ser objeto de investigação pela própria pessoa jurídica interessada e desencadear ação pela advocacia pública competente, nos termos dos arts. 14 e 17, da Lei no 8.429/1992.

Determinados ilícitos administrativos estão sujeitos, ainda, a atuação de outros órgãos do Estado. Apenas para ilustrar a complexidade do aparato de controle no Brasil, os acordos, a combinação, a manipulação ou o ajuste sobre preços, condições, vantagens ou a abstenção em licitação pública podem configurar, simultaneamente, os seguintes tipos de ilícitos:

a) Infração à ordem econômica, nos termos do art. $36, \S 3^{\circ}$, inciso I, alínea "d", da Lei n ${ }^{\circ} 12.529$, de 30 de novembro de 2011, sujeita à apuração e repressão do Conselho Administrativo de Defesa Econômica (Cade);

b) Ato lesivo à Administração Pública, conforme o art. 5º inciso 
IV, da Lei ${ }^{\circ} 12.846$, de $1^{\circ}$ de agosto de 2013, sujeito, na esfera federal, à atuação da Controladoria-Geral da União (CGU) e da pessoa jurídica prejudicada; e

c) Ilícitos financeiros, administrativos e civis que atraem a atuação do próprio TCU e do MPF.

A multiplicidade de órgãos de controle não passou despercebida por Ferraz (2014, p. 33-34), que assinalou que as Leis $n^{\circ} 12.846 / 2013$, 8.429/1992, 1.079, de 10 de abril de 1950, o Decreto-Lei n ${ }^{\circ}$ 201, de 27 de fevereiro de 1967 e a Lei Complementar no 64, de 18 de maio de 1990, prescrevem um microssistema normativo de tutela da ética nas relações político-administrativas no Brasil.

Em verdade, é possível afirmar que existe um microssistema mais amplo de tutela da probidade administrativa, das finanças públicas e de combate à corrupção, sujeito à incidência de um número maior de normas e a atuação simultânea e complementar de vários órgãos.

Nesse cenário, mostra-se relevante estudar as interconexões entre a atuação das diversas instâncias de controle. Especificamente, o presente estudo se limitará a descrever a conexão entre o processo judicial e o de controle externo, no contexto da Operação Lava Jato.

\section{IMPACTO DA ATUAÇÃO DO MPF E DA INSTÂNCIA JUDI- CIAL SOBRE O TCU}

Os processos da Operação Lava Jato geraram alguns impactos na atividade de controle externo. A partir do compartilhamento de provas e informações, o TCU autuou novos processos e ampliou o escopo de alguns trabalhos em andamento. Os tópicos a seguir almejam descrever os efeitos dos atos praticados na esfera judicial sobre as competências da Corte de Contas. 
3.1 Compartilhamento de provas

A primeira forma de interação e influência recíproca entre a instância judicial e a de contas se deu, de modo voluntário, a partir do compartilhamento de informações e evidências entre os agentes dos diversos órgãos competentes.

Segundo Pacelli (2016), "prova compartilhada é aquela produzida em um processo e, mediante autorização daquele juízo, é também levada a outro, mantidas as restrições quanto ao sigilo, acaso presente, e quanto às garantias do contraditório e da ampla defesa".

Considerando os espaços comuns de atuação, especialmente no campo de investigação de ilícitos praticados contra a Administração Pública, é natural que ocorra a produção de elementos de prova úteis às duas instâncias, seja a partir de fiscalizações do TCU, seja a partir de inquéritos do Ministério Público e da polícia judiciária.

Diante do cenário apresentado, de multiplicidade de instância de controles e sobreposições de competências, o intercâmbio de elementos entre as diversas esferas vai ao encontro dos princípios da racionalidade administrativa e da eficiência processual, na medida em que evita a duplicidade de esforços e o desperdício de recursos públicos na instrução de processos, contribuindo para a formação de uma decisão mais célere e fundamentada.

No caso específico do TCU, do MPF e da polícia federal, verificase uma relação de absoluta complementaridade entre as atribuições desses órgãos no controle da legalidade e da economicidade dos atos que dizem respeito à execução de despesa pública.

O MPF e a Polícia Federal, com os instrumentos de investigação que possuem, são mais eficientes na identificação dos crimes e das etapas de consumação dos ilícitos contra a Administração Pública, os quais, em regra, ocorrem de modo não ostensivo. O TCU, por sua vez, atua, primor- 
dialmente, na quantificação dos prejuízos causados ao erário e na verificação de infrações às normas legais ou regulamentares de natureza contábil, financeira, orçamentária, operacional ou patrimonial.

Nesse particular, o Tribunal pode identificar ilícitos ocorridos, ainda, na fase da licitação, tais como a restrição à competitividade no edital do certame, a utilização de projetos básicos deficientes e os direcionamentos no julgamento das propostas, os quais podem servir de suporte à melhor configuração de ilícitos criminais de diversas ordens, tais como o pagamento de propina, lavagem de dinheiro e organização criminosa.

Dessa forma, as provas coletadas nos diversos procedimentos devem ser intercambiadas entre os órgãos de controle igualmente competentes para apurar os fatos conexos, respeitadas as eventuais situações de sigilo dos elementos de prova das investigações.

Tal interação entre as diversas agências de fiscalização está em linha de consonância com a visão de O’Donnell (1998, p. 13), segundo a qual os diversos órgãos da estrutura de controle de um Estado não devem atuar de forma isolada, mas, sim, por meio de "redes de agências", incluindo os Tribunais, todos comprometidos com o accountability. Tal atuação articulada e coordenada favorece o exercício da função de controle e mitiga a ocorrência de erros de julgamentos, pois reduz a assimetria de informações entre os diversos nichos de controle.

No caso específico da Operação Lava Jato, houve uma intensa troca de elementos de prova e informações entre o Tribunal e Ministério Público. O TCU encaminhou, por força do Acórdão no 2.712/2014-Plenário (Relator: Ministro Raimundo Carreiro. Data da Sessão: 15/10/2014), cópia integral de todos os processos concernentes às fiscalizações na Refinaria Abreu e Lima (Rnest), na Refinaria Presidente Getúlio Vargas (Repar) e no Complexo Petroquímico do Rio de Janeiro (Comperj) ao MPF, no Paraná, em atendimento à solicitação formulado por esse órgão. 
$\mathrm{Na}$ via oposta, o juiz responsável pela $13^{\mathrm{a}}$ Vara Federal de Curitiba acolheu pedido formulado pelo MPF, no bojo da Petição $n^{\circ}$ 505474177.2015.4.04.7000/PR e autorizou o compartilhamento dos termos de acordo e de depoimentos dos colaboradores, bem como de documentos e demais elementos pertinentes aos acordos e depoimentos, atuais e futuros, relativas às colaborações homologadas judicialmente, cujos termos/documentos não fossem mais sigilosos ${ }^{2}$.

\subsection{Autuação de novos processos}

A cooperação entre o MPF e o TCU deu ensejo à autuação de representação para apurar a participação de várias empresas em supostas fraudes à licitação nas obras de implantação da Rnest, Repar, Comperj e na usina Angra 3.

Até a conclusão deste trabalho, o Tribunal havia aplicado a sanção de inidoneidade para participar de licitação na Administração Pública Federal, nos termos do art. 46, da Lei $n^{\circ}$ 8.443, de 16 de julho de 1992, a 11 empresas $^{3}$, tendo deixado de imputar a aludida pena para duas sociedades, em função da ausência de provas ${ }^{4}$, e sobrestado a aplicação da sanção para cinco empresas, em razão da celebração de acordos de leniência com o

2 Decisão. Juiz Federal Sérgio Fernando Moro. Data do julgamento: 10/12/2015. Petição $n^{\circ} 5054741$ 77.2015.4.04.7000/PR. Requerente: Ministério Público Federal. Justiça Federal. Seção Judiciária do Paraná. 13 Vara Federal de Curitiba.

3 Acórdãos $n^{\circ}$ s 483/2017-Plenário (Relator: Ministro Bruno Dantas. Data da sessão: 22/3/2017), 1.348/2017-Plenário (Relator: Ministro Bruno Dantas. Data da Sessão: 28/06/2017), 300/2018-Plenário (Relator: Ministro Benjamin Zymler. Data da Sessão: 21/02/2018), 414/2018-Plenário (Relator: Ministro Benjamin Zymler. Data da Sessão: 07/03/2018), 1.221/2018-Plenário (Relator: Ministro Benjamin Zymler. Data da Sessão: 30/05/2018), 1.744/2018-Plenário (Relator: Ministro Benjamin Zymler. Data da Sessão: 01/08/2018), 2.135/2018-Plenário (Relator: Ministro Benjamin Zymler. Data da Sessão: 12/09/2018), 2.355/2018-Plenário (Relator: Ministro Benjamin Zymler. Data da Sessão: 10/10/2018), 424/2019-Penário (Relator: Ministro-Substituto André Luís de Carvalho. Data da Sessão: 27/02/2019), 1.256/2019-Plenário (Relator: Ministro Benjamin Zymler. Data da Sessão: 05/06/2019), 1.527/2019-Plenário (Relator: Ministro Benjamin Zymler. Data da Sessão: 03/07/2019), 2.914/2019-Plenário (Relator: Ministro Benjamin Zymler. Data da Sessão: 04/12/2019), 1.535/2020-Plenário (Relator: Ministro-Substituto André Luís de Carvalho. Data da Sessão: 17/06/2020), 1.900/2020-Plenário (Relator: Ministro Benjamin Zymler. Data da Sessão: 22/07/2020) e 2.134/2020-Plenário (Relator: Ministro-Substituto André Luís de Carvalho. Data da Sessão: $12 / 08 / 2020)$.

4 Acórdãos ns 1.706/2017-Plenário (Relator: Ministro Benjamin Zymler. Data da Sessão: 09/08/2017), 1.083/2019-Plenário (Relator: Ministro Benjamin Zymler. Data da Sessão: 15/05/2019) e 1.354/2020-Plenário (Relator: Ministro-Substituto André Luís de Carvalho. Data da Sessão: 27/05/2020). 
MPF ou com a $\mathrm{CGU}^{5}$. Nos tópicos 4 e 5, serão abordados os casos em que o Tribunal deixou de aplicar a sanção de inidoneidade, devido à celebração de acordos de não persecução com outros órgãos de controle.

\subsection{Ampliação das ações de controle}

Além da autuação de novos processos, a interconexão entre as esferas judicial e de controle externo, no contexto da Operação Lava Jato, possibilitou a abertura de novas frentes de fiscalização e a identificação de outros responsáveis em processos em andamento no TCU.

Por meio do Acórdão $n^{\circ}$ 2.342/2017-Plenário (Relator: Ministro Augusto Sherman. Data da Sessão: 18/10/2017), o Tribunal autorizou a citação de agentes públicos e pessoas físicas em representação acerca de indícios de irregularidades referentes à participação acionária do BNDES Participações S.A. (BNDESPar) na aquisição de empresas frigoríficas norte-americanas.

Conforme se depreende da leitura do voto condutor da deliberação, o Tribunal resolveu incluir outros responsáveis no polo passivo da tomada de contas especial, por força de informações advindas do acordo de colaboração premiada firmado pelos executivos da sociedade empresária Colaboradora.

\section{REPERCUSSÃO DOS ACORDOS DE LENIÊNCIA SOBRE AS COMPETÊNCIAS DO TCU}

A repercussão dos acordos de leniência do MPF sobre a jurisdição de contas suscitou dúvidas e constituiu matéria de defesa das empresas signatárias desses instrumentos em diversos processos levados a cabo no

5 Acórdãos $\mathrm{n}^{\circ}$ s 483/2017-Plenário (Relator: Ministro Bruno Dantas. Data da sessão: 22/3/2017), 1.214/2018-Plenário (Relator: Ministro Benjamin Zymler. Data da sessão: 24/10/2018), 2.446/2018-Plenário (Relator: Ministro Benjamin Zymler. Data da sessão: 24/10/2018), 2.893/2019-Plenário (Relator: Ministro-Substituto André Luís de Carvalho. Data da Sessão: 27/11/2019), 1.690/2020-Plenário (Relator: Ministro Benjamin Zymler. Data da sessão: 01/07/2020) e 1.689/2020-Plenário (Relator: Ministro Bruno Dantas. Data da sessão: 01/07/2020). 
Tribunal. Após um período inicial de incertezas, por conta do próprio ineditismo do instituto da leniência, a jurisprudência do TCU e dos tribunais superiores se consolidar no sentido de que os acordos de não persecução, celebrados pelo MPF, podem espraiar seus efeitos sobre a esfera de controle do TCU, havendo divergências apenas quanto às condições necessárias a essa vinculação.

O presente tópico tem como objetivo apresentar a posição institucional dos diversos órgãos envolvidos nessa temática.

\subsection{Posição da $5^{\mathrm{a}}$ Câmara de Coordenação e Revisão (CCR) do Ministério Público Federal (MPF)}

Para a $5^{\text {a }}$ Câmara de Coordenação e Revisão do MPF ( $5^{\mathrm{a}} \mathrm{CCR} /$ MPF), os acordos celebrados pelo MPF devem repercutir sobre o poder punitivo de outros órgãos de controle, de modo a impedir a aplicação de sanções pelos mesmos fatos ou ilícitos.

Tal conclusão decorreria da relação de prejudicialidade da instância penal frente às demais, do princípio do no bis in idem e das ideias de integridade, coerência e unidade do sistema jurídico, inclusive o repressivo, conforme exposto no Estudo Técnico n ${ }^{\circ}$ 1/2017 - 5ª CCR:

Note-se, a propósito deste aspecto, que, na interdependente relação entre as diversas esferas de responsabilização jurídica, vige, como se sabe, a prejudicialidade da instância penal em relação às demais, já que mais gravosa e abrangente em sua capacidade de atuação. Outro fator que delineia o convívio das diversas instâncias de controle, dotando-as de racionalidade prática, inclusive, é a garantia do ne bis in idem na execução material de sanções aplicadas, quando idênticas ou francamente similares. E, assim como o direito penal é ativado quando valores e bens jurídicos em jogo são considerados relevantes o bastante para atrair grau de proteção mais caro à sociedade e que assegura punição mais gravosa, a ultima ratio, parece adequado reconhecer também que pode ocorrer, na aplicação de 


\section{Entrole}

normas punitivas, espécie de efeitos preclusivos ou suspensão condicionada de mais ampla ação estatal, a partir da consideração de que há suficiência do apenamento consensualmente estabelecido, a dispensar a incidência concreta de outras penas correlatas, especialmente quando há colaboração voluntária de infrator na apuração dos fatos, em resolução negociada de conflitos originados de ações delitivas (BRASIL, 2017b, p. 68, grifo nosso).

Com relação aos danos causados em função dos ilícitos reportados nos acordos de leniência do MPF, a $5^{\text {a }} \mathrm{CCR} / \mathrm{MPF}$ defende, no mesmo estudo, que tais ajustes podem até contemplar, a título de adiantamento, a parcela incontroversa dos prejuízos admitidos pelo colaborador:

Deduz-se, do exposto, que, por sua natureza, em contrapartida às finalidades precípuas do instituto premial, a reparação dos danos ao erário não tem que fazer parte do objeto essencial de acordo de leniência, mas pode nele ser incluida, sobretudo para ser antecipada a restituição da parte incontroversa ou de parcela passível de liquidação adiantada (BRASIL, 2017b, p. 103, grifo nosso).

Pelo que se depreende do exposto, a celebração de leniência não impediria a atuação do TCU no sentido de quantificar o dano e apurar a responsabilidade financeira daqueles que lhe deram causa, ainda que tenha havido algum ressarcimento por ocasião do acordo, que serviria apenas como adiantamento. Todavia, quanto ao exercício do poder sancionatório da Corte de Contas, a celebração do acordo de leniência pelo MPF impediria a aplicação de sanções aos colaboradores em função dos mesmos fatos, de modo que haveria uma vinculação automática da esfera controladora à instância de persecução penal.

Concorda-se em parte com posição da $5^{\mathrm{a}} \mathrm{CCR} / \mathrm{MPF}$. Embora a atuação dos diversos órgãos de controle seja pautada pelo princípio da independência das instâncias, deve-se prestigiar a busca de uniformidade e coerência do poder sancionatório estatal, a qual somente é conseguida 
a partir do espelhamento das decisões proferidas na esfera criminal ou de improbidade administrativa, especialmente as que transacionam sanções.

Todavia, para que o acordo de leniência do MPF possa repercutir na jurisdição de contas, é preciso que o instrumento contemple os mesmos fatos tratados no processo do Tribunal. Nesse caso, presume-se que a cooperação para a atividade de controle externo se dará oportunamente, com a quebra do sigilo dos instrumentos e a remessa posterior das provas obtidas ao Tribunal.

Nessa hipótese, o TCU poderá sobrestar o processo de controle externo até o recebimento das evidências e informações do acordo de leniência. Tão logo isso aconteça, o Tribunal analisará os elementos compartilhados pelo juízo competente, podendo aderir aos termos do acordo de leniência e recuar no exercício do poder sancionatório, caso a cooperação seja útil ao exercício de suas competências.

Se o Tribunal avaliar que os elementos advindos do acordo de leniência não interessam ao exercício de sua função de controle externo, seja porque não promovam alavancagem investigativa, seja porque se reportam a fatos estranhos à sua missão, ele poderá exercer livremente seu poder sancionatório sobre o colaborador, independentemente da celebração de qualquer instrumento de não persecução com o Parquet, recusando as provas recebidas do MPF.

Nesse caso, não há que se falar em supremacia da esfera criminal sobre a de controle externo, uma vez que o acervo probatório da atuação dos órgãos de controle é distinto, preponderando, assim, a independência das instâncias.

\subsection{Posição do TCU}

A questão da repercussão dos acordos de leniência do MPF sobre a jurisdição de contas foi objeto de várias deliberações que atestam uma paulatina evolução da interpretação do instituto pelo órgão de controle externo. 
O primeiro precedente a respeito do tema foi o Acórdão $n^{\circ}$ 1.583/2016-Plenário (Relator: Ministro Benjamin Zymler. Data da Sessão: 22/6/2016). Embora a decisão tivesse natureza preliminar, já que analisou a admissibilidade de representação e ordenou a oitiva das empresas envolvidas em suposto esquema de fraude à licitação na Petrobras, foi consignado, no voto condutor, que o Tribunal "pode considerar evidências extraídas de acordos de leniência e de colaboração, mas a atitude de colaboração dos particulares pode ser considerada na dosimetria de eventuais sanções" (grifos acrescidos).

Posteriormente, o tema foi abordado no Acórdão n ${ }^{\circ}$ 483/2017 - Plenário (Relator: Ministro Bruno Dantas. Data da Sessão: 22/3/2017), dessa feita em decisão de mérito de representação por fraude à licitação em obra da Eletrobras Termonuclear S.A - Eletronuclear. Na ocasião, o TCU sobrestou a apreciação da responsabilidade de empresas que haviam assinado acordo de leniência com o MPF, desde que fossem assinados novos compromissos de colaboração com o MPF quanto aos processos de controle externo deste Tribunal (Recall).

No Acórdão n ${ }^{\circ}$ 1.214/2018-Plenário (Relator: Ministro Benjamin Zymler. Data da Sessão: 30/5/2018), o Tribunal pela primeira vez deixou de aplicar sanção de inidoneidade à empresa signatária de acordo de leniência com o MPF, sem condicionar a medida à assinatura de um novo compromisso de colaboração com o Ministério Público Federal.

$\mathrm{Na}$ ocasião, o TCU levou em conta os fatos de que a sociedade empresária havia admitido a participação no ilícito e tinha sido a primeira a trazer informações e provas sobre os fatos em apuração no Tribunal, o que permitiu a atuação do controle externo, inclusive para abrir processos contra outras empresas. A seguinte passagem do voto expressa a ratio decidendi adotada:

O TCU pode valorar e levar em conta as colaborações premiadas e os acordos de leniência celebrados pelo Ministério Públi- 
co e outras instâncias de controle que tratem dos mesmos fatos analisados em seus processos, principalmente se elas forem úteis ao exercício das competências de controle externo.

Pelo exposto, seriam três as condições para a repercussão de acordos de leniência do MPF sobre a jurisdição de contas: o ineditismo das informações e evidências trazidas pelo colaborador; a identidade de objeto entre o acordo e o processo do TCU (no mínimo, uma relação de continência entre eles); e a utilidade das informações e provas decorrentes do acordo de colaboração para a atividade de controle externo.

Posteriormente, o TCU evoluiu nesse entendimento, ao admitir, no Acórdão no 2.446/2018 - Plenário (Relator: Ministro Benjamin Zymler. Data da Sessão: 24/10/2018), a repercussão de acordo de leniência do MPF que tratava de fatos já conhecidos pelo Tribunal, de modo que o processo em apreciação não dependia das informações e evidências fornecidas no acordo.

A título de contextualização, a matéria em discussão na deliberação era a participação de empresa na mesma fraude à licitação reportada pela sociedade empresária que teve isenção de pena no Acórdão no 1.214/2018 - Plenário. No caso, havia informações e evidências suficientes, decorrentes do acordo de leniência da primeira empresa, para a condenação da segunda.

Todavia, o TCU resolveu reconhecer os efeitos do segundo acordo de leniência sobre a sua jurisdição, de forma a não aplicar sanção à signatária desse instrumento (segunda colaboradora), sob o argumento de que havia utilizado provas compartilhadas anteriormente pela esfera judicial, o que impunha uma atuação uniforme com essa instância de controle.

Assim, o Tribunal acolheu os fundamentos expostos pelo Relator no sentido de que era necessário prestigiar o dever de coerência do aparato estatal de proteção de atos ilícitos praticados contra a Administração Pública, especialmente quando há intercâmbio de elementos de prova for- 
necidas em função de acordos de colaboração. Em suas palavras:

55. [...] Se a cooperação de uma pessoa junto a outra instância foi suficiente para evitar a aplicação de sanção pela violação de bem jurídico, também tutelado pelo o TCU, o Tribunal deve, numa atitude de deferência ao acordo firmado por outro órgão de controle e de respeito ao microssistema de combate à corrupção e de defesa da probidade administrativa, diante da ausência de provas autônomas em relação à produzida por aquela instância, recuar no exercício de seu poder sancionatório e reputar como suficiente a pena ou a medida substitutiva imputada pelo órgão do Estado (grifo nosso).

Tomando por base esses fundamentos, o Tribunal decidiu sobrestar a apreciação da participação da empresa na fraude à licitação discutida no processo, até a demonstração de que a sociedade cumpriu suas obrigações no acordo de leniência do MPF e no termo de compromisso de cessação de prática do Cade. Outros exemplos de consideração dos efeitos dos acordos, celebrados pelo MPF, sobre a jurisdição de contas são:

a) Acórdão no 2.677/2018 - Plenário (Relator: Ministro Benjamin Zymler. Data da Sessão: 21/11/2018): julgou irregulares as contas de agentes privados que haviam assinado acordo de colaboração premiada e de empresa que firmou acordo de leniência com o MPF, mas deixou de aplicar a sanção do art. 47, da Lei n ${ }^{\circ}$ 8.443/1992; e

b) Acórdãos no 954 e 955/2019 - Plenário (Relator: Ministro Benjamin Zymler. Data da Sessão: 30/4/2019): sobrestaram a aplicação à apreciação da participação de pessoas físicas que haviam pactuado acordo de colaboração premiada com o MPF, até a demonstração de que eles cumpriram suas obrigações nos referidos ajustes.

Sendo assim, é possível verificar a sedimentação do entendimento de que a colaboração geral perante o Estado, mediante a celebração de acordo de leniência com o MPF, repercute na jurisdição do TCU, desde que a instância judicial tenha deixado de aplicar sanção ao colaborador pelos mesmos fatos apurados pelo TCU. 
Todavia, com relação ao ressarcimento dos danos causados ao erário em função do ilícito, a celebração de acordo de leniência não tem nenhum impacto sobre a jurisdição de contas. A questão foi enfrentada inicialmente no Acórdão no 1.411/2017 - Plenário (Relator: Augusto Sherman. Data da Sessão: 5/7/2017), que ordenou a citação de responsável a partir que havia assinado esse instrumento.

Na ocasião, o Tribunal negou eficácia à cláusula do acordo que impedia o uso das informações contra o colaborador, aspecto que será enfrentado no próximo tópico, e concluiu que esse instrumento não afastava o dever constitucional do TCU de apurar a responsabilidade financeira de quem causou prejuízos ao erário, inclusive do próprio colaborador. Nas palavras do Ministro Relator:

\begin{abstract}
Entendo que a obtenção de reparação do dano é objetivo tanto nos acordos de leniência quanto nos acordos de colaboração premiada, e o fato de não ser um resultado necessário para a eficácia desse último significa apenas que, paralelamente à reparação, existem outros objetivos também significativos para o processo judicial penal. Entendo, entretanto, que o sentido da lei é o de que o acordo de colaboração deve procurar atingir o maior número de objetivos possível, se possível todos eles, mas, em nenhuma hipótese, porque seria contraditório, o de o acordo estabelecer condição que possa impedir o atingimento de qualquer um deles.
\end{abstract}

Esse entendimento foi referenciado expressamente nos votos dos Acórdãos no 1.214/2018-Plenário e 2.446/2018-Plenário, já mencionados, e foi adotado no Acórdão n ${ }^{\circ}$ 2.677/2018-Plenário, também destacado, que condenou em débito vários responsáveis, inclusive colaboradores. Essa posição está em linha de consonância com a da $5^{\mathrm{a}} \mathrm{CCR} / \mathrm{MPF}$, segundo a qual a celebração de acordo de leniência não impede a atuação do TCU no sentido de quantificar o dano e apurar a responsabilidade financeira, conforme exposto no item 3.1.

Diverge-se da posição do TCU, de ampla aceitação dos acordos de 
leniência do MPF quando do exercício de seu poder sancionatório, independentemente do uso ou não das provas advindas desses instrumentos. Isso porque tal entendimento implica o reconhecimento a priori de uma posição de supremacia institucional da instância criminal sobre a controladora, a qual somente incide no caso de absolvição criminal que negue a existência do fato ou sua autoria.

Em nossa visão, o Tribunal somente estaria condicionado ao pactuado em acordo de leniência do MPF, caso ele aderisse ao instrumento e decidisse aproveitar as provas dele decorrente, após o regular compartilhamento, para fins de exercício de sua competência (alavancagem investigativa da função de controle externo). Com relação ao débito, o entendimento do TCU e do MPF está alinhado com o texto constitucional.

\subsection{Posição monocrática do Supremo Tribunal Federal}

Sobre o tema, cabe destacar, ainda, decisão monocrática proferida pelo Ministro Gilmar Mendes, no âmbito de mandado de segurança preventivo, com pedido de liminar, impetrado por empresa signatária de acordo de leniência com o MPF, em face da alegada possibilidade iminente de ser declarada inidônea pelo TCU.

Em cognição sumária e tratando, evidentemente, apenas dos pressupostos para a concessão da cautelar, o Ministro Gilmar Mendes deferiu cautelar impedindo a decretação de inidoneidade da impetrante, mas ressalvou a possibilidade de o TCU julgar as contas e imputar prejuízos à empresa, mesmo que ela tenha assinado acordo de leniência com o Ministério Público (MS 35.435 MC / DF, Relator: Ministro Gilmar Mendes. Data da decisão: 13/4/2018).

Conforme a deliberação, repita-se, em cognição não exauriente, a celebração de acordo de leniência repercutiria apenas no poder do TCU de declarar a inidoneidade da signatária do instrumento por fatos contemplados no 
acordo, não abrangendo outras competências relacionadas ao débito. Tal entendimento está de acordo com a posição do TCU exposta no tópico anterior.

A discussão do mérito do mandado de segurança foi iniciada em $26 / 05 / 2020^{6}$, de forma que o relator proferiu voto conjunto confirmando a liminar anterior e concedendo a ordem, para o fim de impedir a decretação de inidoneidade de empresa que tenha celebrado acordo de leniência com o MPF e com a CGU/AGU, haja vista o dever de uniformidade e coerência dos órgãos integrantes do microssistema de combate à corrupção.

Pelo didatismo das conclusões entabuladas a respeito do acordo de leniência da CGU/AGU, que, pela lógica da fundamentação do relator, também se aplicam aos instrumentos homônimos celebrados pelo MPF, transcreve-se a seguinte passagem do voto proferido na oportunidade:

\begin{abstract}
A possibilidade de o TCU impor sanção de inidoneidade pelos mesmos fatos que deram ensejo à celebração de acordo de leniência com a CGU/AGU não é compatível com os princípios constitucionais da eficiência e da segurança jurídica.

Embora a sanção de inidoneidade aplicada com base na Lei 8.443/1992 não esteja contemplada expressamente na Lei Anticorrupção (Lei 12.846/2013), a aplicação desta penalidade pela Corte de Contas resultará em ineficácia da cláusula que prevê a isenção ou a atenuação das sanções administrativas estabelecidas nos arts. 86 a 88 da Lei 8.666/1993, por consequência, esvaziando a força normativa do art. 17 da Lei 12.846/2013, pois os efeitos práticos das sanções mencionadas são semelhantes, senão coincidentes.
\end{abstract}

Cabe destacar que o julgamento dos mandados de segurança foi suspenso na ocasião, após o Ministro Édson Fachin acompanhar o relator apenas com relação ao MS 35.435. Ainda faltam votar os ministros Ricardo Lewandowski, Celso de Mello e Cármen Lúcia ${ }^{7}$.

$6 \quad$ O relator reuniu, no mesmo julgamento, outros mandados de segurança interpostos a outras empresas, envolvendo o mesmo suporte fático, a contratação das obras da Usina Nuclear de Angra III (MS 35435, 36173, 36496 e 36526$)$.

7 Informações extraídas do próprio sítio eletrônico do STF - Disponível em: http://www.stf.jus.br/portal/ cms/verNoticiaDetalhe.asp?idConteudo=444177. Acesso em: 8 nov. 2020. 
A conclusão desse julgado será importante para a sedimentação do entendimento sobre o tema em análise, embora a questão possa ser revisitada pelo próprio STF, em eventuais julgamentos levados ao colegiado da Casa, especialmente com repercussão geral.

\section{QUESTÕES CONTROVERTIDAS EM RAZÃO DA INTERCONEXÃO DO PROCESSO DE CONTAS COMO PROCESSO JUDICIAL}

Várias questões se põem na relação entre o TCU e os diversos órgãos de controle. $O$ presente tópico tem como objetivo tratar de algumas indagações que surgem a partir da interconexão do processo de contas com o processo judicial.

5.1 É possível o TCU usar prova compartilhada por outra instância contra responsável que celebrou acordo de colaboração nessa instância?

A questão foi enfrentada, inicialmente, no Acórdão $\mathrm{n}^{\circ}$ 1.411/2017-Plenário, supramencionado, que discutiu a possibilidade jurídica de citação de responsável por irregularidades reveladas em acordo de colaboração premiada assinado por ele junto ao MPF, tendo em vista, especialmente, a existência da cláusula que vedava o uso de prova em prejuízo do colaborador ${ }^{8}$.

$\mathrm{Na}$ fundamentação de seu voto, o Ministro Relator pontuou que a vontade das partes, entabuladas em acordo de colaboração, não poderia contrariar norma de direito público que assegura a terceiro, que não fez parte do acordo, o uso de provas emprestadas de outro processo.

Ademais, ele destacou a impossibilidade de extensão dos benefícios da colaboração premiada à esfera civil, a finalidade do instituto de permi$8 \quad$ Cláusula $19^{\mathrm{a}}$ [...] Parágrafo Terceiro. O compartilhamento das provas produzidas neste acordo para fins de utilização nas esferas cíveis e administrativas não poderá ser feito em prejuízo do próprio colaborador (BRASIL, 2017b). 
tir a recuperação total do produto ou do proveito das infrações penais praticadas e as competências constitucionais do TCU de julgar contas, apurar a responsabilidade financeira de quem der causa à perda ou prejuízo ao erário e de aplicar as sanções previstas em lei. Segundo o voto condutor da decisão:

não há impedimento para a citação do Colaborador com fundamento nas provas e informações por ele fornecidas no acordo de colaboração, no presente processo de tomada de contas especial, que tem por objetivo apurar a ocorrência de dano ao erário e, se for o caso, buscar sua reparação.

O Tribunal enfrentou novamente $\mathrm{o}$ tema no Acórdão $\mathrm{n}^{\mathrm{o}}$ 1.214/2018-Plenário, já referenciado, que tratou de suposta participação de empresa que havia celebrado acordos de leniência junto ao MPF e ao Cade em fraudes à licitação ocorridas na Petrobras.

A questão ganhou contornos especiais frente ao decidido na deliberação anterior, pois o que se discutiu na ocasião não foi o uso de provas contra o colaborador para fins de ressarcimento, mas sim de aplicação sanção.

No voto condutor da decisão, o Ministro Relator assinalou que o uso de prova fornecida por colaborador contra ele mesmo para fins sancionatórios depende de sua expressa anuência, tendo em vista o direito de não autoincriminação e dos princípios da boa-fé subjetiva e da proteção da confiança legítima do colaborador. Em suas palavras:

34. No presente caso, considerando que o colaborador trouxe provas na legítima expectativa de não sofrer as consequências jurídicas além daquelas que pactuou no próprio acordo, cabe prestigiar a confiança que ele depositou no Estado para o fim de não se admitir o uso de prova ou informação fornecida por colaborador, em acordo celebrado com o Ministério Público ou pelo Cade, para imputar-lhe sanções de mesma natureza em razão desses fatos. 
35. Por esses motivos, apesar de demonstrada a ocorrência do ilícito tipificado no art. 46 da Lei 8.443/1992, reputo incabivel utilizar os elementos de prova trazidos pela Colaboradora e seus executivos para sancionar a aludida empresa com a declaração de inidoneidade (grifo nosso).

Esse entendimento está de acordo com a tese que defendi em trabalho anterior, no sentido de que o uso de prova fornecida por colaborador contra ele mesmo está sujeito ao princípio da comunhão ou aquisição condicionada, quando compartilhada a outras instâncias:

A transferência de tais provas a outros processos deve ter como premissa o respeito ao direito de propriedade do colaborador sobre tais coisas e, por conseguinte, os termos do negócio jurídico entabulado entre ele e o Estado. As provas coletadas em função dos acordos de leniência e de colaboração premiada estão sujeitas ao princípio da comunhão ou aquisição condicionada ou mitigada (ALVES, 2019, p. 236).

No mesmo sentido, a Segunda Turma do STF, em julgamento do Agravo Regimental na Petição n ${ }^{0}$ 7065, admitiu o compartilhamento de provas advindas de acordo de leniência para instrução de inquérito civil, mas ressalvou a impossibilidade de as evidências serem usadas em prejuízo do colaborador. Nas palavras do Ministro Relator, “a utilização de tais elementos probatórios, produzidos pelo próprio colaborador, em seu prejuízo, de modo distinto do firmado com a acusação e homologado pelo Judiciário é prática abusiva, que viola o direito à não autoincriminação" (BRASIL, 2018d).

No Acórdão $n^{\circ}$ 2.446/2018-Plenário, supramencionado, a questão ganhou outros contornos, tendo em vista o despacho proferido pelo juiz titular da $13^{\mathrm{a}}$ Vara Federal de Curitiba, no bojo da Petição 505474177.2015.4.04.7000/PR .

9 Decisão. Juiz Federal Sérgio Fernando Moro. Data do julgamento: 02/04/2018. Petição $n^{\circ}$ 505474177.2015.4.04.7000/PR. Requerente: Ministério Público Federal. Justiça Federal. Seção Judiciária do Paraná. 13a Vara Federal de Curitiba. 
No referido processo judicial, o juiz autorizou o compartilhamento dos elementos e das informações decorrentes de acordos de colaboração já homologados para outras instâncias, desde que não sigilosos, com a finalidade de instruir procedimentos e processos penais ou extrapenais.

Após requerimento formulado pelo MPF, o juiz titular da $13^{\mathrm{a}}$ Vara Federal de Curitiba emitiu novo despacho, restringindo o uso de provas compartilhadas contra colaborador, nos termos assinalados a seguir:

\begin{abstract}
Ante o exposto, defiro o requerido pelo MPF e promovo o aditamento de todas as referidas decisões para a elas agregar que está vedada a utilização dos elementos informativos e provas cujo compartilhamento foi anteriormente autorizado por este Juízo contra pessoas que celebraram acordo de colaboração com o Ministério Público no âmbito da assim denominada Operação Lava Jato, bem como contra empresas que celebraram acordo de leniência

Caso pretendida a utilização das provas ou das informações com esta finalidade, ficará ela sujeita à autorização específica deste Juízo, ou seja, da apresentação de novo requerimento.
\end{abstract}

Como se vê, a decisão vedou a utilização de evidências compartilhadas pelo juízo contra o colaborador, independentemente do fato de as provas terem sido produzidas pelo próprio colaborador, ampliando, portanto, a ideia inicial defendida no Acórdão $\mathrm{n}^{\circ}$ 1.214/2018-Plenário, supramencionado, que apenas inadmitia o uso de prova decorrente de sua própria colaboração.

Foi por essa razão, que o Ministro Relator, no Acórdão $\mathrm{n}^{0}$ 2.446/2018-Plenário, decidiu desconsiderar todas as provas compartilhadas pela $13^{\circ}$ Vara Federal de Curitiba para fins de aplicação de sanção do art. 46, da Lei ${ }^{\circ} 8.443 / 1992$, como visto.

A matéria decidida no aludido despacho sofreu, posteriormente, novo aditamento, tendo em vista a ocorrência de dúvidas sobre a extensão da decisão anterior sobre os processos que apuram prejuízos ao erário. 
Atendendo ao expediente, encaminhado pelo Presidente do TCU, o juízo proferiu nova decisão ${ }^{10}$, ressalvando a possibilidade de utilização de provas compartilhadas contra colaborador para fins de ressarcimento de danos. Seguem as considerações emanadas pelo juízo:

O próprio conteúdo dos acordos de colaboração e de leniência é no sentido de que eles não eximem os colaboradores e lenientes da obrigação de reparar o dano decorrente de suas atividades ilícitas por completo.

Normalmente, os acordos preveem multas indenizatórias calculadas por estimativa, não havendo condições ótimas para apurar todos os danos decorrentes dos ilícitos.

Assim, é o caso de, na esteira da manifestação do MPF, autorizar o Tribunal de Contas da União a utilizar as provas compartilhadas mesmo contra colaboradores ou empresas lenientes para o fim exclusivo de ressarcimento dos danos decorrentes do crime.

Esse contexto fático e jurisprudencial foi utilizado nos Acórdãos no 954 e 955/2019-Plenário, já aludidos, que não aproveitaram as provas compartilhadas pelo juízo e decidiram sobrestar a aplicação de sanção às pessoas arroladas no processo que haviam assinado acordo de colaboração premiada com o MPF.

Como se vê, o posicionamento do TCU atualmente é convergente com os do MPF e do juízo federal de Curitiba que concentra os processos judiciais conexos aos apreciados pela Corte de Contas, usados como referência neste trabalho.

Reputa-se adequada a posição atual dos órgãos, uma vez que o uso de prova advinda de acordos de não persecução deve obedecer às condições estatuídas nos referidos instrumentos, as quais se estendem às demais instâncias que queiram usufruir dos elementos de prova deles advindos.

$\overline{10}$ Decisão. Juiz Federal Sérgio Fernando Moro. Data do julgamento: 02/10/2018. Petição $n^{\circ}$ 505474177.2015.4.04.7000/PR. Requerente: Ministério Público Federal. Justiça Federal. Seção Judiciária do Paraná. 13ª Vara Federal de Curitiba. 
5.2 O TCU pode decretar a indisponibilidade de bens de empresas signatárias de acordos de leniência?

Quanto ao assunto, a posição inicial do TCU era no sentido de que não havia óbice à decretação de indisponibilidade de bens de empresas que tivessem celebrado acordo de leniência com o MPF. Posteriormente, esse entendimento evoluiu de modo que, atualmente, o Tribunal tem deixado de adotar essa medida restritiva para empresas que tenham assinado tais instrumentos, desde que seja comprovada que a contribuição dessa pessoa foi útil para a apuração dos fatos em análise no processo do Tribunal.

Todavia, cabe ressaltar a existência de precedente no âmbito do Tribunal Regional Federal da $4^{\text {a }}$ Região, admitindo a possibilidade de expedição dessa cautelar, em processo de improbidade administrativa, sobre pessoa jurídica signatária de acordo de leniência.

\subsubsection{Posição do TCU}

A medida cautelar de indisponibilidade de bens está prevista no art. $44, \S 2^{\circ}$, da Lei $n^{\circ} 8.443 / 1992^{11}$. Para que o Tribunal adote essa medida cautelar, basta que estejam presentes os pressupostos inerentes a qualquer provimento cautelar, quais sejam, a fumaça do bom direito e o perigo da demora.

Como é cediço, os acordos de leniência do MPF têm como objetivo, sob o ponto dos benefícios aos seus signatários, reduzir as sanções que lhe seriam cabíveis na esfera de persecução penal e de improbidade administrativa, não havendo efeitos quanto ao ressarcimento ao erário, já que o MPF não tem dado quitação do débito aos colaboradores.

Porém, a jurisprudência do TCU vem evoluindo no sentido de não

11 Art. 44. [...] $\S 2^{\circ}$ Nas mesmas circunstâncias do caput deste artigo e do parágrafo anterior, poderá o Tribunal, sem prejuízo das medidas previstas nos arts. 60 e 61 desta Lei, decretar, por prazo não superior a um ano, a indisponibilidade de bens do responsável, tantos quantos considerados bastantes para garantir o ressarcimento dos danos em apuração. 
decretar a indisponibilidade de bens de colaboradores, a fim de prestigiar a integridade do instituto e permitir o cumprimento de seus termos. No Acórdão $n^{\circ}$ 2.109/2016-Plenário (Relator: Ministro Benjamin Zymler. Data da Sessão: 17/8/2016), o Tribunal decidiu, pela primeira vez, não decretar a indisponibilidade de bens de pessoas físicas signatárias de acordo de colaboração premiada.

Conforme exposto pelo Ministro Relator, buscou-se preservar a integridade do instituto, após a unidade técnica verificar que vários documentos fornecidos foram usados para se comprovar a ilicitude de contratos analisados pelo TCU:

\begin{abstract}
88. Acolho tal conclusão, que, em essência, busca manter a integridade do instituto da delação premiada, enfatizando que ainda subsiste a obrigação de ressarcimento ao erário. Acrescento que não existiria motivos para alguém colaborar no âmbito criminal se remanescesse a possibilidade de sua punição em outras esferas.
\end{abstract}

A partir de então, foram prolatadas várias deliberações nas quais a Corte de Contas deixou de decretar a indisponibilidade de bens de empresas e pessoas físicas que haviam assinado acordo de leniência ou de colaboração premiada com o MPF, sem condicionar a manutenção da decisão à futura colaboração com o TCU ${ }^{12}$.

Todavia, existem precedentes nos quais foram estabelecidas condi-

12 Acórdãos no ${ }^{\circ}$ 2.428/2016-Plenário (Relator: Ministro Benjamin Zymler. Data da Sessão: 21/9/2016), 632/2017-Plenário (Relator: Ministro Aroldo Cedraz. Data da Sessão: 5/4/2017) e 1.083/2017-Plenário (Relator: Ministro-Substituto André Luís de Carvalho. Data da Sessão: 24/05/2017), 2.014/2017-Plenário (Relator: Ministro Bruno Dantas. Data da Sessão: 13/9/2017), 1.399/2018-Plenário (Relator: Ministro-Substituto André Luís de Carvalho. Data da Sessão: 23/8/2017), 2.396/2018-Plenário (Relator: Ministro Benjamin Zymler. Data da Sessão: 17/10/2018), 59/2019-Plenário (Relator: Ministro-Substituto André Luís de Carvalho. Data da Sessão: 23/1/2019), 128/2019-Plenário (Relator: Ministro-Substituto André Luís de Carvalho. Data da Sessão: 30/1/2019), 213/2019-Plenário (Relator: Ministro-Substituto André Luís de Carvalho. Data da Sessão: 6/2/2019), 366/2019-Plenário (Relator: MinistroSubstituto André Luís de Carvalho. Data da Sessão: 20/2/2019), 368/2019-Plenário (Relator: Ministro-Substituto André Luís de Carvalho. Data da Sessão: 20/2/2019), 510/2019-Plenário (Relator: Ministro-Substituto André Luís de Carvalho. Data da Sessão: 13/3/2019), 642/2019-Plenário (Relator: Ministro-Substituto André Luís de Carvalho. Data da Sessão: 20/3/2019), 644/2019-Plenário (Relator: Ministro-Substituto André Luís de Carvalho. Data da Sessão: 20/3/2019), 722/2019-Plenário (Relator: Ministro-Substituto André Luís de Carvalho. Data da Sessão: 27/3/2019), 723/2019-Plenário (Relator: Ministro-Substituto André Luís de Carvalho. Data da Sessão: 27/3/2019).

Rev. Controle, Fortaleza, v. 19, n.1, p. 354-392, jan./jun. 2021. 
ções à não adoção dessa providência cautelar.

No Acórdão ${ }^{\circ}$ 1.831/2017-Plenário (Relator: Ministro Benjamin Zymler. Data da Sessão: 23/8/2017), o Tribunal deixou de adotar essa medida cautelar sobre empresa signatária de acordo de leniência do MPF, mas o Relator ressalvou que o TCU poderia rever tal encaminhamento no futuro, caso não houvesse efetiva colaboração com o processo de controle externo, em especial para a recuperação dos prejuízos.

No Acórdão n ${ }^{\circ}$ 2.791/2017-Plenário (Relator: Ministro-Substituto André Luís de Carvalho. Data da Sessão: 6/12/2017), o TCU decretou a indisponibilidade de bens de colaboradores perante o MPF, mas sobrestou a aplicação dessa medida e condicionou esse sobrestamento à comprovação da efetiva cooperação perante o Ministério Público e os processos de controle externo.

Há, ainda, precedente no qual foi exigida a identidade entre o objeto da colaboração e o do processo do Tribunal. Nesse sentido, invoca-se o Acórdão no 1.083/2017-Plenário (Relator: Ministro-Substituto André Luís de Carvalho. Data da Sessão: 24/05/2017), no qual foi decretada a indisponibilidade de bens de empresa signatária de acordo de leniência, por não haver evidências de que a colaboração da empresa abarcava os fatos analisados no processo do Tribunal.

$\mathrm{Na}$ ocasião, o Ministro Relator registrou que o TCU poderia reavaliar a decisão, caso ficasse demonstrado, após o contraditório, que a colaboração da empresa havia sido relevante para a elucidação dos ilícitos relacionados ao empreendimento fiscalizado pelo Tribunal. Seguem as suas considerações:

De todo modo, no que concerne ao efeito do acordo judicial de colaboração premiada sobre a eventual condenação dos responsáveis no âmbito do TCU, anoto que, por ocasião da futura apreciação do referido pedido de cautelar e das propostas de mérito no presente feito, o TCU vai ter de ponderar cada conduta ilícita perpetrada em desfavor do acervo da Repar e 
do patrimônio da Petrobras, de sorte que, na oportunidade, o TCU poderá sopesar o grau de colaboração de cada responsável, na qualidade de pessoa física ou até de representante legal da pessoa jurídica, para a efetiva elucidação judicial dos malfeitos infligidos aos aludidos contratos da Repar, no âmbito da Operação Lava Jato (com a devida homologação judicial), podendo o TCU, conforme as circunstâncias, deixar de aplicar as penalidades legais ao efetivo colaborador.

No Acórdão n ${ }^{\circ} 387 / 2018$-Plenário (Relator: Ministro Vital do Rego. Data da Sessão: 28/2/2018), o Tribunal decidiu decretar a indisponibilidade de bens de pessoa física signatária de acordo de colaboração premiada, sob o argumento que o referido ajuste contemplava valores que não possibilitavam o ressarcimento integral ao erário. Nas palavras do Ministro Relator:

\begin{abstract}
Além do que já expus, há duas considerações relevantes. A primeira é que as indenizações acordadas não alcançam os prejuízos associados ao Colaborador na aquisição da Refinaria de Pasadena, cerca de US\$ 580 milhões. A segunda é que a cautelar se justifica por abranger itens patrimoniais que não foram expressamente previstos no termo de colaboração premiada, a exemplo de imóveis e bens móveis que estão bloqueados em razão da deliberação desta Corte e não integram os termos da colaboração [...].

Nessa toada, o termo de colaboração em exame tem seu foco na recuperação de bens e valores que foram obtidos por meio da prática de crimes. Por sua vez, o processo de TCE deste Tribunal intenciona o ressarcimento integral do dano, independentemente de o agente ter obtido vantagens ou não com a conduta que culminou na causa do prejuízo.
\end{abstract}

Há precedente mais recente no qual o TCU decretou a indisponibilidade dos bens de empresa signatária, de acordo de leniência com o MPF, nos termos do Acórdão $n^{\circ}$ 874/2018-Plenário (Relator: Ministro Bruno Dantas. Data da Sessão: 25/4/2018). 
Na ocasião, o Ministro Relator acolheu o posicionamento da unidade técnica de que cabia a aludida medida restritiva, uma vez que a empresa, até o momento, ainda não havia, de fato, colaborado com a jurisdição de contas, especificamente para a quantificação do débito. Conforme aduzido no voto:

\begin{abstract}
A unidade instrutora argumenta que, embora tenha sido firmado acordo de leniência com a Colaboradora, a empresa não tem adotado postura efetivamente colaborativa no que tange aos processos que tramitam nesta Corte. A unidade chama atenção ao fato de a empresa não ter admitido, até o momento, a participação nas irregularidades ora tratadas, nem apresentado documentação fiscal e contábil que comprovasse, com segurança, os custos reais por ela incorridos. Defende, portanto, que a existência desse pacto não seria suficiente para que se deixasse de adotar a medida constritiva de bens nesta oportunidade.
\end{abstract}

Como se vê, a posição majoritária do TCU oscila entre a impossibilidade de decretação de indisponibilidade de bens de colaborador perante o MPF e a possibilidade de adoção dessa medida cautelar, nesse caso, se a colaboração da empresa não abarcar os fatos analisados no processo do Tribunal; se o valor da indenização pactuada no acordo de leniência ou de colaboração não assegurar o ressarcimento integral do débito; ou se não houver colaboração efetiva para o processo de controle externo, em especial para a reparação do débito.

Somos da opinião que a celebração de acordo de leniência pelo MPF não deveria interferir sobre a medida cautelar de indisponibilidade de bens decretada pelo TCU, uma vez que ela é instrumental ao ressarcimento do débito, o qual, conforme visto, não é impactado pela celebração de instrumentos de leniência. 


\subsubsection{Posição adotada no âmbito do juízo federal}

Em ação de improbidade administrativa interposta pela Advocacia Geral da União (AGU), o juiz federal encarregado do processo determinou, liminarmente o bloqueio de bens de empresa signatária, de acordo de leniência com o MPF ${ }^{13}$. Tomando por base petição do Parquet, o juiz federal revogou a tutela provisória concedida em face da empresa que celebrou acordo de leniência ${ }^{14}$.

A aludida deliberação foi objeto de agravo de instrumento interposto pela AGU. A $3^{\mathrm{a}}$ Turma do Tribunal Regional Federal da $4^{\mathrm{a}}$ Região apreciou a matéria e decidiu dar provimento ao recurso para determinar novamente o bloqueio dos bens da empresa signatária do acordo de leniência ${ }^{15}$. Conforme a ementa do aludido julgado:

10. A autoridade competente para firmar o acordo de leniência, no âmbito do Poder Executivo Federal é a Controladoria Geral da União (CGU).

$[\ldots]$

12. O acordo de leniência firmado pelo Colaborador no âmbito administrativo necessita ser re-ratificado pelo ente competente, com participação dos demais entes, levando-se em conta o ressarcimento ao erário e a multa, sob pena de não ensejar efeitos jurídicos válidos.

13. Enquanto não houver a re-ratificação do acordo de leniência, a empresa deverá permanecer na ação de improbidade, persistindo o interesse no bloqueio dos bens, não porque o MP não pode transacionar sobre as penas, mas porque o referido acordo possui vícios que precisam ser sanados para que resulte íntegra sua validade, gerando os efeitos previstos naquele ato negocial (grifo nosso).

13 Decisão. Juiz Federal Friedmann Anderson Wendpap. Data do julgamento: 23/11/2016. Ação de Improbidade Administrativa $n^{\circ}$ 5025956-71.2016.4.04.7000/PR. Autor: União - Advocacia Geral da União. Justiça Federal. Seção Judiciária do Paraná. $1^{\text {a }}$ Vara Federal de Curitiba.

14 Decisão. Juiz Federal Friedmann Anderson Wendpap. Data do julgamento: 24/03/2017. Ação de Improbidade Administrativa $n^{\circ}$ 5025956-71.2016.4.04.7000/PR. Autor: União - Advocacia Geral da União. Justiça Federal. Seção Judiciária do Paraná. $1^{\text {a }}$ Vara Federal de Curitiba.

15 Acórdão. Ministra Relatora: Vânia Hack de Almeida. Data da Sessão: 22/08/2017. Agravo de Instrumento n ${ }^{\circ}$ 5023972-66.2017.4.04.0000/PR. Agravante: União - Advocacia Geral da União. Justiça Federal. Tribunal Regional Federal da $4^{\mathrm{a}}$ Região. 
Como se vê, a possibilidade de decretação de indisponibilidade de bens de empresa signatária de acordo de leniência com o MPF levou em conta unicamente o entendimento do juízo ad quem no sentido de que o órgão competente para celebrar tais instrumentos era a CGU, de modo que, sem a ratificação do acordo por esse órgão, não haveria nenhum efeito na esfera civil.

Embora essa decisão não tenha tratado da decretação de indisponibilidade de bens pelo TCU, é possível deduzir que os seus pressupostos também se aplicariam à atuação da Corte de Contas, pois a tese defendida foi a de que o acordo de leniência do MPF não teria efeitos na esfera civil.

A matéria não teve outros desdobramentos, pois, posteriormente, a CGU/AGU assinaram acordo de leniência com a empresa, o que motivou o pedido de homologação do instrumento e de desistência da ação de improbidade, o qual foi deferido pelo juízo competente ${ }^{16}$.

De todo modo, o fundamento adotado pelo tribunal ad quem encontra-se superado, já que, após as recentes alterações ocorridas na Lei $\mathrm{n}^{\circ}$ 8.429/1992, por força da $\mathrm{n}^{\circ} 13.964$, de 24 de dezembro de 2019, o MPF está legitimado a firmar acordo de não persecução cível, na esfera de improbidade administrativa, caindo por terra, portanto, o argumento de que o acordo de leniência do MPF não tem repercussão civil.

\section{CONSIDERAÇÕES FINAIS}

A existência de vários nichos de controle, cada um com competências específicas e, por vezes, sobrepostas, traz, em si, o problema da falta de coerência e compatibilidade da atuação estatal, especialmente, no que se refere ao exercício do poder punitivo. Se, antes, os reflexos da atuação de um órgão de controle sobre a de outro, no que se refere à aplicação de

16 Decisão. Juíza Federal Thaís Sampaio da Silva Machado. Data do julgamento: 15/10/2018. Ação de Improbidade Administrativa $n^{\circ}$ 5025956-71.2016.4.04.7000/PR. Autor: União - Advocacia Geral da União. Justiça Federal. Seção Judiciária do Paraná. $1^{\text {a }}$ Vara Federal de Curitiba. 
sanções por ofensa aos mesmos bens jurídicos, já causavam dúvidas e suscitavam discussões, em razão do princípio do no bis in idem, a situação ficou ainda complexa, com o advento do instituto da leniência.

O presente estudo teve o propósito de estudar a evolução do processo de contas a partir da sua interconexão com o processo judicial, após o advento da paradigmática Operação Lava Jato. De substancial, o trabalho verificou que houve um incremento na qualidade dos elementos de prova coligidos na etapa de instrução do processo de controle externo, a partir do compartilhamento de informações e documentos advindos de processos judiciais da referida operação.

Essa vantagem foi acompanhada de um ônus ao sistema processual do TCU, qual seja a tarefa de se debruçar sobre elementos de prova que não faziam parte do cotidiano de um tribunal de contas, tais como degravações telefônicas, documentos fiscais, escriturações contábeis internas de empresas contratadas e outras peças oriundas da atividade policial.

Essa abertura a um universo, até então desconhecido, por força das próprias competências do TCU, exigiu um esforço adicional no manuseio e no tratamento de um número significativo de informações e documentos, além daqueles já manipulados na atividade de controle externo. $\mathrm{O}$ aprendizado decorrente desse período de transição deve ser útil para que o TCU aperfeiçoe a sua interação com outros órgãos de controle e, por consequência, consiga oferecer à sociedade uma decisão mais bem informada, fundamentada e justa.

Como exposto, várias dúvidas foram opostas ao processo de controle externo por conta dessa interconexão entre as diversas esferas de controle, especificamente no tratamento jurídico dos signatários de acordos de leniência.

A evolução natural da jurisprudência, fruto da apreciação de casos concretos, permitiu a decantação das questões interpretativas surgidas, de modo que, atualmente, é possível ver uma atuação mais harmônica entre as 
diversas instâncias de controle, no sentido de uma maior eficiência do microssistema de combate à corrupção e defesa da probidade administrativa.

O próximo desafio é construir um balcão único para a celebração de acordos de não persecução, envolvendo um conjunto maior de órgãos de controle, nas esferas administrativa, judicial e controladora, de forma a permitir uma maior abrangência dos elementos de prova a serem fornecidos pelo colaborador e a otimização da busca pelo ressarcimento integral do dano causado ao erário. As mudanças institucionais necessárias a esse objetivo devem ser objetos de reflexão da academia e dos órgãos envolvidos e constituem uma fonte de inspiração para uma pesquisa futura.

\section{REFERÊNCIAS}

ALVES, F. S. M. A. Utilização pela jurisdição de contas das provas fornecidas em acordos de leniência e de colaboração premiada em desfavor do colaborador: análise da possibilidade à luz da teoria da aquisição da prova. Revista Interesse Público, Belo Horizonte, v. 113, p. 211-238, 2019.

BRASIL. Justiça Federal. Seção Judiciária do Paraná. $1^{a}$ Vara Federal de Curitiba. Ação de Improbidade Administrativa no 502595671.2016.4.04.7000/PR. Juiz Federal Friedmann Anderson Wendpap. Data do julgamento 23/11/2016. Brasília, DF: STF, 2016a. Disponível em: https://bit.ly/38Fuu5m. Acesso em: 7 nov. 2020.

BRASIL. Justiça Federal. Seção Judiciária do Paraná. Ação de Improbidade Administrativa $n^{\circ}$ 5025956-71.2016.4.04.7000/PR. Juíza Federal Thaís Sampaio da Silva Machado. Data do julgamento 15/10/2018. Brasília, DF: STF, 2018a. Disponível em: https://bit.ly/38Fuu5m. Acesso em: 7 nov. 2020. 
BRASIL. Justiça Federal. Seção Judiciária do Paraná. 13a Vara Federal de Curitiba. Petição n ${ }^{0}$ 5054741-77.2015.4.04.7000/PR. Juiz Federal Sérgio Fernando Moro. Data do julgamento: 10/12/2015. Brasília, DF: STF, 2015. Disponível em: https://bit.ly/38Fuu5m. Acesso em: 7 nov. 2020.

BRASIL. Justiça Federal. Seção Judiciária do Paraná. Vara Federal de Curitiba. Petição n ${ }^{0}$ 5054741-77.2015.4.04.7000/PR. Juiz Federal Sérgio Fernando Moro. Data do julgamento: 02/04/2018. Brasília, DF: STF, 2018b. Disponível em: https://bit.ly/38Fuu5m. Acesso em: 7 nov. 2020.

BRASIL. Justiça Federal. Seção Judiciária do Paraná. Vara Federal de Curitiba. Petição n ${ }^{0}$ 5054741-77.2015.4.04.7000/PR. Juiz Federal Sérgio Fernando Moro. Data do julgamento: 02/10/2018. Brasília, DF: STF, 2018c. Disponível em: https://bit.ly/38Fuu5m. Acesso em: 7 nov. 2020.

BRASIL. Justiça Federal. Seção Judiciária do Paraná. Supremo Tribunal Federal. Segunda Turma. Agravo Regimental Petição no ${ }^{0}$ 7065. Ministro Relator: Édson Fachin. Data da Sessão: 30/10/2018. Brasília, DF: STF, 2018d. Disponível em: https://bit.ly/2K7Wzbl. Acesso em: 7 nov. 2020.

BRASIL. Justiça Federal. Seção Judiciária do Paraná. $2^{\mathrm{a}}$ Turma: compartilhamento de termos de colaboração deve observar cláusulas do acordo. Notícias do STF, Brasília, DF, 2018e. Disponível em: https://bit. ly/35uhD4c. Acesso em: 7 nov. 2020.

BRASIL. Justiça Federal. Seção Judiciária do Paraná. Tribunal Regional Federal da $4^{\mathrm{a}}$ Região. Agravo de Instrumento $\mathrm{n}^{\mathrm{o}}$ 502397266.2017.4.04.0000/PR. Ministra Relatora: Vânia Hack de Almeida. Data da Sessão: 22/08/2017. Brasília, DF: STF, 2017a. Disponível em: https:// bit.ly/38Fuu5m. Acesso em: 7 nov. 2020. 
BRASIL. Ministério Público Federal. Estudo Técnico no 1/2017 - 5 CCR, de setembro de 2017. Brasília, DF: MPF, 2017b. Disponível em: https://bit.ly/32FWeTA. Acesso em: 7 nov. 2020.

BRASIL. Tribunal de Contas da União. Processo no ${ }^{0}$ TC 016.119/20169. Acórdão $n^{0}$ 1.583/2016-Plenário. Relator: Ministro Benjamin Zymler. Data da Sessão: 22/6/2016. Brasília, DF: TCU, 2016b. Disponível em: https://bit.ly/3pqheYn. Acesso em: 7 nov. 2020.

BRASIL. Tribunal de Contas da União. Processo n⿳0 016.991/2015-0. Acórdão n 483/2017-Plenário. Relator: Ministro Bruno Dantas. Data da Sessão: 22/3/2017. Brasília, DF: TCU, 2017c. Disponível em: https://bit. ly/3pqheYn. Acesso em: 7 nov. 2020.

BRASIL. Tribunal de Contas da União. Processo n⿳0 019.707/2014-2. Acórdão $\mathrm{n}^{\circ}$ 2.712/2014-Plenário. Relator: Ministro Raimundo Carreiro. Data da Sessão: 15/10/2014. Brasília, DF: TCU, 2014. Disponível em: https://bit.ly/3pqheYn. Acesso em: 7 nov. 2020.

BRASIL. Tribunal de Contas da União. Processo n⿳0 023.266/2015-5. Acórdão n 1.083/2017-Plenário. Relator: Ministro-Substituto André Luís de Carvalho. Data da Sessão: 24/05/2017. Brasília, DF: TCU, 2017d. Disponível em: https://bit.ly/3pqheYn. Acesso em: 7 nov. 2020.

BRASIL. Tribunal de Contas da União. Processo $n^{\mathbf{0}}$ 021.542/2016-3. Acórdão $n^{\circ}$ 1.348/2017-Plenário. Relator: Ministro Bruno Dantas. Data da Sessão: 28/06/2017. Brasília, DF: TCU, 2017e. Disponível em: https:// bit.ly/3pqheYn. Acesso em: 7 nov. 2020. 
BRASIL. Tribunal de Contas da União. Processo n ${ }^{0}$ 010.398/2017-1. Acórdão ${ }^{\circ}$ 1.411/2017-Plenário. Relator: Augusto Sherman. Data da Sessão: 5/7/2017. Brasília, DF: TCU, 2017f. Disponível em: https://bit.ly/3pqheYn. Acesso em: 7 nov. 2020.

BRASIL. Tribunal de Contas da União. Processo n ${ }^{0}$ 013.388/2017-7. Acórdão $\mathrm{n}^{\circ}$ 1.706/2017-Plenário. Relator: Ministro Benjamin Zymler. Data da Sessão: 09/08/2017. Brasília, DF: TCU, 2017g. Disponível em: https://bit.ly/3pqheYn. Acesso em: 7 nov. 2020.

BRASIL. Tribunal de Contas da União. Processo n ${ }^{0}$ 004.056/2015-9. Acórdão $\mathrm{n}^{\circ}$ 1.831/2017-Plenário. Relator: Ministro Benjamin Zymler. Data da Sessão: 23/8/2017. Brasília, DF: TCU, 2017h. Disponível em: https://bit.ly/3pqheYn. Acesso em: 7 nov. 2020.

BRASIL. Tribunal de Contas da União. Processo $\mathbf{n}^{0}$ 034.931/2015-5. Acórdão $\mathrm{n}^{\circ}$ 2.342/2017-Plenário. Relator: Ministro Augusto Sherman. Data da Sessão: 18/10/2017. Brasília, DF: TCU, 2017i. Disponível em: https://bit.ly/3pqheYn. Acesso em: 7 nov. 2020.

BRASIL. Tribunal de Contas da União. Processo n ${ }^{0}$ 023.301/2015-5. Acórdão no 2.791/2017-Plenário. Relator: Ministro-Substituto André Luís de Carvalho. Data da Sessão: 6/12/2017. Brasília, DF: TCU, 2017j. Disponível em: https://bit.ly/3pqheYn. Acesso em: 7 nov. 2020.

BRASIL. Tribunal de Contas da União. Processo n ${ }^{0}$ 013.387/2017-0. Acórdão no 300/2018-Plenário. Relator: Ministro Benjamin Zymler. Data da Sessão: 21/02/2018. Brasília, DF: TCU, 2018f. Disponível em: https:// bit.ly/3pqheYn. Acesso em: 7 nov. 2020. 
BRASIL. Tribunal de Contas da União. Processo n⿳ 005.406/2013-7. Acórdão no 387/2018-Plenário. Relator: Ministro Vital do Rego. Data da Sessão: 28/2/2018. Brasília, DF: TCU, 2018g. Disponível em: https://bit. ly/3pqheYn. Acesso em: 7 nov. 2020.

BRASIL. Tribunal de Contas da União. Processo $n^{0}$ 013.386/2017-4. Acórdão no 414/2018-Plenário. Relator: Ministro Benjamin Zymler. Data da Sessão: 07/03/2018. Brasília, DF: TCU, 2018h. Disponível em: https:// bit.ly/3pqheYn. Acesso em: 7 nov. 2020.

BRASIL. Tribunal de Contas da União. Processo $n^{0}$ 002.651/2015-7. Acórdão no 874/2018-Plenário. Relator: Ministro Bruno Dantas. Data da Sessão: 25/4/2018. Brasília, DF: TCU, 2018i. Disponível em: https://bit. ly/3pqheYn. Acesso em: 7 nov. 2020.

BRASIL. Tribunal de Contas da União. Processo n⿳0 021.226/2017-2. Acórdão $\mathrm{n}^{\mathrm{o}}$ 1.214/2018-Plenário. Relator: Ministro Benjamin Zymler. Data da Sessão: 30/5/2018. Brasília, DF: TCU, 2018j. Disponível em: https://pesquisa.apps.tcu.gov.br/\#/pesquisa/acordao-completo. Acesso em: 7 nov. 2020.

BRASIL. Tribunal de Contas da União. Processo n⿳ 013.383/2017-5. Acórdão $\mathrm{n}^{\circ}$ 1.221/2018-Plenário. Relator: Ministro Benjamin Zymler. Data da Sessão: 30/05/2018. Brasília, DF: TCU, 2018k. Disponível em: https://bit.ly/3pqheYn. Acesso em: 7 nov. 2020.

BRASIL. Tribunal de Contas da União. Processo no 013.382/2017-9. Acórdão $\mathrm{n}^{\circ}$ 1.744/2018-Plenário. Relator: Ministro Benjamin Zymler. Data da Sessão: 01/08/2018. Brasília, DF: TCU, 20181. Disponível em: https://bit.ly/3pqheYn. Acesso em: 7 nov. 2020. 
BRASIL. Tribunal de Contas da União. Processo n ${ }^{0}$ 013.384/2017-1. Acórdão $\mathrm{n}^{\circ}$ 2.135/2018-Plenário. Relator: Ministro Benjamin Zymler. Data da Sessão: 12/09/2018. Brasília, DF: TCU, 2018m. Disponível em: https://bit.ly/3pqheYn. Acesso em: 7 nov. 2020.

BRASIL. Tribunal de Contas da União. Processo n ${ }^{0}$ 013.385/2017-8. Acórdão $\mathrm{n}^{\circ}$ 2.355/2018-Plenário. Relator: Ministro Benjamin Zymler. Data da Sessão: 10/10/2018. Brasília, DF: TCU, 2018n. Disponível em: https://bit.ly/3pqheYn. Acesso em: 7 nov. 2020.

BRASIL. Tribunal de Contas da União. Processo n ${ }^{0}$ 036.335/2016-9. Acórdão $\mathrm{n}^{\circ}$ 2.446/2018-Plenário. Relator: Ministro Benjamin Zymler. Data da Sessão: 24/10/2018. Brasília, DF: TCU, 2018o. Disponível em: https://bit.ly/3pqheYn. Acesso em: 7 nov. 2020.

BRASIL. Tribunal de Contas da União. Processo $\mathbf{n}^{\mathbf{0}}$ 000.168/2016-5. Acórdão $\mathrm{n}^{\circ}$ 2.677/2018-Plenário. Relator: Ministro Benjamin Zymler. Data da Sessão: 21/11/2018. Brasília, DF: TCU, 2018p. Disponível em: https://bit.ly/3pqheYn. Acesso em: 7 nov. 2020.

BRASIL. Tribunal de Contas da União. Processo n ${ }^{0}$ 013.395/2017-3. Acórdão no 954/2019-Plenário. Relator: Ministro Benjamin Zymler. Data da Sessão: 30/4/2019. Brasília, DF: TCU, 2019a. Disponível em: https:// bit.ly/3pqheYn. Acesso em: 7 nov. 2020.

BRASIL. Tribunal de Contas da União. Processo n ${ }^{0}$ 013.397/2017-6. Acórdão n ${ }^{\circ}$ 955/2019-Plenário. Relator: Ministro Benjamin Zymler. Data da Sessão: 30/4/2019. Brasília, DF: TCU, 2019b. Disponível em: https:// bit.ly/3pqheYn. Acesso em: 7 nov. 2020. 
BRASIL. Tribunal de Contas da União. Processo $\mathbf{n}^{0}$ 013.394/2017-7. Acórdão $\mathrm{n}^{\circ}$ 1.083/2019-Plenário. Relator: Ministro Benjamin Zymler. Data da Sessão: 15/05/2019. Brasília, DF: TCU, 2019c. Disponível em: https://bit.ly/3pqheYn. Acesso em: 7 nov. 2020.

FERRAZ, L. Reflexões sobre a Lei $\mathrm{n}^{\circ} 12.846 / 2013$ e seus impactos nas relações público-privadas: lei de improbidade empresarial e não lei anticorrupção. Revista Brasileira de Direito Público, Belo Horizonte, n. 47, p. 33-43, 2014.

O'DONNELL, G. Horizontal accountability in new polyarchies. Kellogg Institute, South Bend, n. 253, 1998. Disponível em: https://bit.ly/3pqRLxV. Acesso em: 7 nov. 2020.

PACELLI, E. Prova compartilhada. GenJurídico, São Paulo, 11 jan. 2016. Disponível em: https://bit.ly/2Iz58vn. Acesso em: 7 nov. 2020. 